\title{
Thermostable Alkaline Phytase from Alcaligenes sp. in Improving Bioavailability of Phosphorus in Animal Feed: In Vitro Analysis
}

\author{
Ponnuswamy Vijayaraghavan, ${ }^{1}$ R. Raja Primiya, ${ }^{2}$ and Samuel Gnana Prakash Vincent ${ }^{3}$ \\ ${ }^{1}$ Centre for Marine Science and Technology, Manonmaniam Sundaranar University, Rajakkamangalam, \\ Kanyakumari, Tamil Nadu 629 502, India \\ ${ }^{2}$ P. G. Department of Microbiology, Ayya Nadar Janaki Ammal College, Sivakasi, Tamil Nadu 626 124, India \\ ${ }^{3}$ International Centre for Nanobiotechnology, Centre for Marine Science and Technology, Manonmaniam Sundaranar University, \\ Rajakkamangalam, Kanyakumari District, Tamil Nadu 629 502, India
}

Correspondence should be addressed to Ponnuswamy Vijayaraghavan; venzymes@gmail.com

Received 31 December 2012; Accepted 17 January 2013

Academic Editors: H. S. Garcia, G. Ladics, C. D. Murphy, S. Pan, H. Stamatis, and A. Trincone

Copyright (C) 2013 Ponnuswamy Vijayaraghavan et al. This is an open access article distributed under the Creative Commons Attribution License, which permits unrestricted use, distribution, and reproduction in any medium, provided the original work is properly cited.

\begin{abstract}
A bacterial isolate, Alcaligenes sp. secreting phytase (EC 3.1.3.8), was isolated and characterized. The optimum conditions for the production of phytase included a fermentation period of $96 \mathrm{~h}, \mathrm{pH} 8.0$, and the addition of $1 \%(\mathrm{w} / \mathrm{v})$ maltose and $1 \%(\mathrm{w} / \mathrm{v})$ beef extract to the culture medium. This enzyme was purified to homogeneity and had an apparent molecular mass of $41 \mathrm{kDa}$. The optimum $\mathrm{pH}$ range and temperature for the activity of phytase were found to be $7.0-8.0$ and $60^{\circ} \mathrm{C}$, respectively. This enzyme was strongly inhibited by $0.005 \mathrm{M}$ of $\mathrm{Mn}^{2+}, \mathrm{Mg}^{2+}$, and $\mathrm{Zn}^{2+}$. In vitro studies revealed that the phytase from Alcaligenes sp. released inorganic phosphate from plant phytates. Phytase released $1930 \pm 28,1740 \pm 13,1050 \pm 31,845 \pm 7,1935 \pm 32$, and $1655 \pm 21 \mathrm{mg}$ inorganic phosphate/kg plant phytates, namely, chick pea, corn, green pea, groundnut, pearl pea, and chick feed, respectively.
\end{abstract}

\section{Introduction}

Phytate-degrading enzyme (phytase, EC 3.1.3.8) preparations have a wide range of applications in animal and human nutrition. Besides that, these enzymes have also attracted considerable attention from both scientists and entrepreneurs in the areas of environmental protection and biotechnology. Phytases are of great interest in biotechnological applications, in particular for the reduction of phytate content in feed and food [1]. Phytases are capable of initiating the stepwise release of myoinositol and phosphoric acid, leading to the formation of myoinositol phosphate intermediates from phytate [2]. Most plant-origin foods have from $50 \%$ to $80 \%$ of their total phosphorus as phytate [3]. Phytate chelates essential minerals, binds to amino acids and proteins, inhibits digestive enzymes, and decreases the nutritive value of food [4]. Monogastric animals poorly utilized phytate-bound phosphorus, due to insufficient phytate-degrading activity in the gut [5].
Therefore, hydrolysis of phytate is desirable for releasing valuable nutrients for beneficial utilization. The addition of phytate-degrading enzymes can improve the nutritional value of plant-based foods by enhancing protein digestibility and mineral availability through phytate hydrolysis during digestion in the stomach or during food processing [6], thus reducing the phosphorus excretion of animals [7].

Only a limited number of bacterial phytases have been reported and studied [8]. Phytase has been isolated from bacteria such as Escherichia coli [9], Pseudomonas sp. [10], anaerobic rumen bacteria, particularly Selemonas ruminantium, Megasphaera elsdenii, Prevotella sp., Mitsuokella multiacidus [11], and Raoultella sp. [12]. Numerous studies have shown the effectiveness of supplemental microbial phytases in improving the utilization of phosphate from phytate [13]. Naturally occurring phytases having the required level of thermostability for application in animal feeds have not been 
found [14]. Hence, the main objective of the present study was to characterize alkaline- thermostable phytase from Alcaligenes sp., and possible application in in vitro digestion of plant phytate was evaluated. A study of this kind will improve our knowledge on the biotechnological application of phytase in feed industry.

\section{Materials and Methods}

2.1. Bacterial Culture and Screening. The bacterial isolate, Alcaligenes sp., was obtained from the Microbiology Laboratory, Centre for Marine Science and Technology, M. S. University, Rajakkamangalam, Tamil Nadu, India. To screen phytase-producing microorganism effectively, the plate agar method was followed [15]. Sodium phytate (2\%, w/v) was added as substrate in plate screening media. The Alcaligenes sp. was grown on this solid medium and incubated at $37^{\circ} \mathrm{C}$ for $48 \mathrm{~h}$. Phytase plate screening was carried out by washing the colonies with distilled water from the agar surface and flooding the plate with $2 \%(\mathrm{w} / \mathrm{v})$ cobalt chloride solution and incubated for $30 \mathrm{~min}$ at room temperature. Then replaced the cobalt chloride solution with a freshly prepared solution containing equal volume of $6.25 \%(\mathrm{w} / \mathrm{v})$ ammonium molybdate and $0.42 \%(\mathrm{w} / \mathrm{v})$ ammonium vanadate solution. Following further $30 \mathrm{~min}$ incubation the solution removed and the plates were examined for zones of clearing which indicates phytase activity.

2.2. Phytase Production. Phytase-secreting Alcaligenes sp. was subjected for phytase production in the production medium (containing 1 litre: sodium phytate, $10 \mathrm{~g}$; $\left(\mathrm{NH}_{4}\right)_{2} \mathrm{SO}_{4}$, $1 \mathrm{~g} ; \mathrm{MgSO}_{4} \cdot 7 \mathrm{H}_{2} \mathrm{O}, 0.1 \mathrm{~g} ; \mathrm{CaCl}_{2} \cdot 2 \mathrm{H}_{2} \mathrm{O}, 0.1 \mathrm{~g}$; trace element solution, $1.0 \mathrm{~mL}$; $\mathrm{KCl}, 0.7 \mathrm{~g}$; glucose, $1 \mathrm{~g}$; D-mannose, $1 \mathrm{~g}$ ). The $\mathrm{pH}$ of the medium was adjusted to 7.0 by using $1 \mathrm{~N} \mathrm{HCl} / 1 \mathrm{~N}$ $\mathrm{NaOH}$. Sodium phytate was filter-sterilized separately, and added after autoclaving, to the production medium. A loopfull of bacterial culture was transferred to $150 \mathrm{~mL}$ of phytase production medium in a $250-\mathrm{mL}$ Erlenmeyer flask, and the culture was incubated at $37^{\circ} \mathrm{C}$ with shaking at $150 \mathrm{rpm}$. For the determination of the growth curve, $5 \mathrm{~mL}$ of the culture medium was withdrawn at regular intervals of $12 \mathrm{~h}$ and the cell density determined at $600 \mathrm{~nm}$ up to $120 \mathrm{~h}$. To study the optimum incubation time for phytase production, the culture was withdrawn every $12 \mathrm{~h}$ and centrifuged at $10,000 \times \mathrm{g}$ for $15 \mathrm{~min}$. The culture supernatant was assayed for determining enzyme activity. Effect of $\mathrm{pH}$ on enzyme production was studied by adjusting the culture medium $\mathrm{pH}$ to $6.0,7.0,8.0,9.0$, and 10.0 by the addition of $1 \mathrm{~N}$ $\mathrm{HCl} / \mathrm{NaOH}$ prior to sterilization. To study the effect of carbon and nitrogen sources on enzyme production, the organism was grown in the production medium containing additional $1 \%(\mathrm{w} / \mathrm{v}$ ) carbon (arabinose, dextrose, maltose, sucrose, trehalose, mannose, and starch) and nitrogen sources (urea, ammonium sulphate, peptone, ammonium chloride, and beef extract). All experiments were conducted in triplicates and average values were reported.
2.3. Crude Enzyme Preparation and Phytase Assay. Bacterial culture was prepared for assay as suggested by Yanke et al. [11]. A cell-free extract was prepared from $96 \mathrm{~h}$-old culture by centrifuging it at $10,000 \times \mathrm{g}$ for $15 \mathrm{~min}$. The culture supernatant was assayed for determining phytase activity, which was based on the estimation of inorganic phosphate released on hydrolysis of phytic acid, at $37^{\circ} \mathrm{C}$. One unit of enzyme activity was defined as the amount of enzyme that liberates $1 \mu \mathrm{mol}$ of inorganic phosphate per minute under standard assay conditions. The liberated inorganic phosphate was measured according to the ammonium molybdate method [16]. The total protein content of the sample was estimated as described by Lowry et al. [17], and bovine serum albumin was used as the standard.

2.4. Properties of Alcaligenes Phytase. The optimum $\mathrm{pH}$ for the enzyme activity was determined by using the following buffers $(0.1 \mathrm{M})$ : citrate buffer $(\mathrm{pH} 4.0)$, succinate buffer $(\mathrm{pH}$ 5.0-6.0), tris-acetate buffer $(\mathrm{pH} 7.0)$, tris- $\mathrm{HCl}$ buffer $(\mathrm{pH}$ 8.0), and glycine- $\mathrm{NaOH}$ buffer ( $\mathrm{pH} 9.0$ ). The stability of the enzyme at various $\mathrm{pH}$ was examined by incubating the enzyme solution in buffers ranging in $\mathrm{pH}$ from 4 to 9 at $37^{\circ} \mathrm{C}$ for $30 \mathrm{~min}$; enzyme activity was assayed as described earlier. The temperature profile of the enzyme was determined by performing the routine enzyme assay at varying incubation temperatures $\left(30,40,50,60\right.$, and $\left.70^{\circ} \mathrm{C}\right)$. To determine the thermal stability of the enzyme, it was incubated for 30$70^{\circ} \mathrm{C}$ for $30 \mathrm{~min}$ before performing the routine enzyme assay. The effect of divalent ions and chemicals on enzyme activity was determined by incubating the enzyme with various divalent ions and chemicals $(0.005 \mathrm{M})$, namely, $\mathrm{Ca}^{2+}$, $\mathrm{Mn}^{2+}, \mathrm{Zn}^{2+}, \mathrm{Cu}^{2+}, \mathrm{Mg}^{2+}$, ethylenediaminetetraacetic acid (EDTA), dithiothreitol, and $\beta$-mercaptoethanol for $30 \mathrm{~min}$. The enzyme activity was assayed as described earlier.

2.5. Purification of Extracellular Alcaligenes Phytase. The crude enzyme preparation $(140 \mathrm{~mL})$ was fractionated with ammonium sulphate ( $60 \%$ to $80 \%$ saturation) as suggested by $\mathrm{Fu}$ et al. [18]. The protein precipitate was dissolved in a minimal volume of double-distilled water and the resulting enzyme was dialyzed against the buffer A (tris-HCl buffer, $0.025 \mathrm{M}, \mathrm{pH} 8.0$ ) overnight at $4^{\circ} \mathrm{C}$. The dialyzed sample was subjected to Diethyl-aminoethyl cellulose (DEAE cellulose) chromatography (Merck, Bangalore, India) using buffer A, and the bounded protein was eluted with a linear gradient of $\mathrm{NaCl}(0-1 \mathrm{M})$. The fractions having phytase activity were combined and concentrated using ammonium sulphate $(80 \%$ saturation) and dialyzed against buffer B (tris- $\mathrm{HCl}$ buffer, $0.05 \mathrm{M}, \mathrm{pH} 8.0$ ). The concentrated sample was loaded on a preequilibrated sephadex G-75 column (Amersham Biosciences, SE-751 84, Uppsala, Sweden) and eluted with buffer B.

2.6. Polyacrylamide Gel Electrophoresis. Sodium dodecyl sulphate-polyacrylamide gel electrophoresis (SDS-PAGE) was performed according to Laemmli [19]. The stacking gel was $5 \%(\mathrm{w} / \mathrm{v})$ polyacrylamide, and the separating gel was $11 \%(\mathrm{w} / \mathrm{v})$ polyacrylamide. The active fraction obtained from 
the sephadex G-75 column was subjected to electrophoresis. After electrophoresis, the gel was treated and stained for phytase activity as described by Yanke et al. [11], with a cobalt chloride solution followed by an ammonium molybdate/ammonium vanadate solution. The gel was documented using a gel documentation system (Syngene, Cambridge, CB4 1TF, UK) and the molecular weight of the purified enzyme determined.

2.7. In Vitro Hydrolysis of Plant Phytate. An in vitro experiment was performed to study the hydrolysing efficacy of Alcaligenes phytase on plant phytate [18]. Briefly, plant phytates from various sources, namely, chick pea, corn, green pea, groundnut, pearl pea, and chick feed named "Layer Mash" brought from the local market were used. All materials were ground into coarse powder and sieved $(0.2-0.3 \mathrm{~mm})$. Two grams of the above material were placed in a $50-\mathrm{mL}$ conical flask. To this, $10 \mathrm{U}$ crude enzyme and $5 \mathrm{~mL}$ of buffer B were added and the mixture was placed in an orbital shaker at $150 \mathrm{rpm}$ for $30 \mathrm{~min}$. A control experiment was carried out separately; for this, $10 \mathrm{~mL}$ of buffer $\mathrm{B}$ alone was applied to the raw materials. To the reaction mixture, $10 \mathrm{~mL}$ trichloroacetic acid $(15 \%)$ was added to stop the reaction. The released inorganic phosphorus was determined [19].

\section{Results and Discussion}

3.1. Screening of Phytase Secreting Alcaligenes sp. The isolate, Alcaligenes sp. secreted alkaline phytase when it was grown on phytase screening medium. This organism produced a 2.0$\mathrm{mm}$ zone around the colony after $48 \mathrm{~h}$. This organism was used for further studies.

3.2. Growth and Phytase Production. The Alcaligenes sp. attained maximum growth after $72 \mathrm{~h}$ of fermentation, and the absorbance was $1.972 \pm 0.036$ at $600 \mathrm{~nm}$. The absorbance declined to $1.728 \pm 0.027,1.615 \pm 0.039,1.619 \pm 0.781$, and $1.407 \pm 0.033$ at 84,96 , and $108 \mathrm{~h}$ of incubation, respectively. The isolate produced an interesting phytase when grown in minimal medium containing sodium phytate as the sole source of phosphorus. The enzyme secretion increased to its maximum of $6.202 \pm 0.082 \mathrm{U} / \mathrm{mL}$ at $96 \mathrm{~h}$ of fermentation. Enzyme production was found to be $0.008 \pm 0.005,1.811 \pm$ $0.221,4.351 \pm 0.192$, and $3.610 \pm 0.191 \mathrm{U} / \mathrm{mL}$ at $24,48,72$, and $120 \mathrm{~h}$ of fermentation, respectively, (Figure 1). In this organism, phytase was expressed on the onset of late log phase. The reduction in enzyme yield after the optimum period was probably due to the depletion of nutrients that are available to microorganism. This result was in accordance with the observation made with Yersinia kristensenii [18].

3.3. Effect of $\mathrm{pH}$ on Enzyme Production. Effect of $\mathrm{pH}$ on enzyme production was studied by culturing the organism at various $\mathrm{pH}$ levels $(6.0-10.0)$ using $1 \mathrm{~N} \mathrm{HCl} / \mathrm{NaOH}$. Phytase production was $1.5 \pm 0.15,2.96 \pm 0.16,2.0 \pm 0.23,1.7 \pm$ $0.10 \mathrm{U} / \mathrm{mL}$ at $\mathrm{pH}$ 6.0, 7.0, 9.0, and 10.0, respectively. Enzyme production was found to be high at $\mathrm{pH} 8.0(4.9 \pm 0.18 \mathrm{U} / \mathrm{mL})$. At high $\mathrm{pH}$ level (9.0), phytase production decreased. At

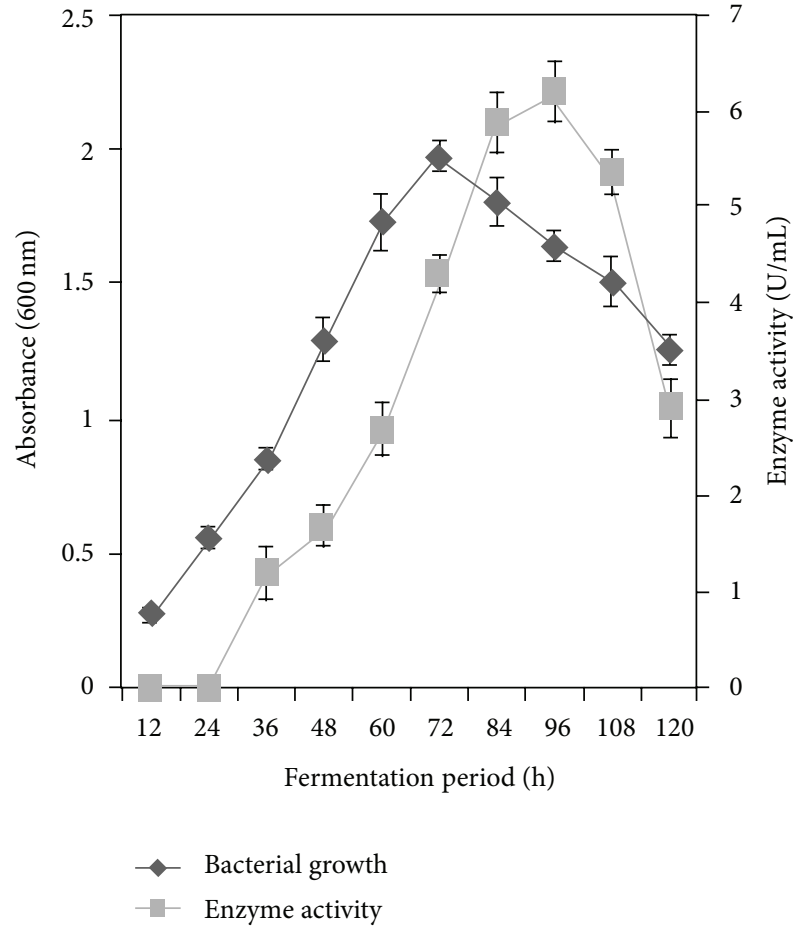

Figure 1: Growth and production of phytase from Alcaligenes sp. The isolate was inoculated and incubated for $120 \mathrm{~h}$ at $37^{\circ} \mathrm{C}$. The culture was withdrawn every $12 \mathrm{~h}$, and the growth enzyme activity was determined. The result was the mean of three different repeats. The error bar indicates standard deviation.

higher $\mathrm{pH}$, the metabolic action of the bacterium may be suppressed and thus enzyme production decreased. This result was in accordance with the observations made with Mitsuokella jalaludinii by Lan et al. [20].

3.4. Effect of Carbon and Nitrogen Sources on Enzyme Production. Phytase production was found to be high $(6.2 \pm$ $0.018 \mathrm{U} / \mathrm{mL}$ ) in the production medium supplemented with $1 \%(\mathrm{w} / \mathrm{v})$ maltose. Enzyme production was $5.0 \pm 0.032,4.33 \pm$ $0.01,4.8 \pm 0.05,3.47 \pm 0.09$, and $3.07 \pm 0.008 \mathrm{U} / \mathrm{mL}$ in the production medium containing starch, dextrose, trehalose, sucrose, and arabinose, respectively. Mannose (1\%, w/v) repressed the production of phytase. Similar results were obtained with Bacillus sp. KHU-10 [21]. Phytase production was high $(6.5 \pm 0.026 \mathrm{U} / \mathrm{mL})$ in the production medium containing beef extract $(1 \%, w / v)$ as the sole source of nitrogen. Enzyme production was $3.35 \pm 0.05,3.0 \pm 0.03$, $4.6 \pm 0.13$, and $5.2 \pm 0.08 \mathrm{U} / \mathrm{mL}$ in production medium containing urea, ammonium sulphate, peptone, and ammonium chloride, respectively. This result was in accordance with the observation made with Bacillus sp. KHU-10 [21].

3.5. Effect of pH on Enzyme Activity and Stability. In Alcaligenes sp. phytase activity was found to be high (100\% activity) at $\mathrm{pH}$ 8.0. The relative enzyme activity was $0.9 \pm 0.13 \%$, $3.4 \pm 0.18 \%, 44.5 \pm 3.4,98 \pm 5.5 \%$, and $40 \pm 2.2 \%$ at pH 4.0 , $5.0,6.0,7.0$, and 9.0 , respectively. This enzyme was also highly 


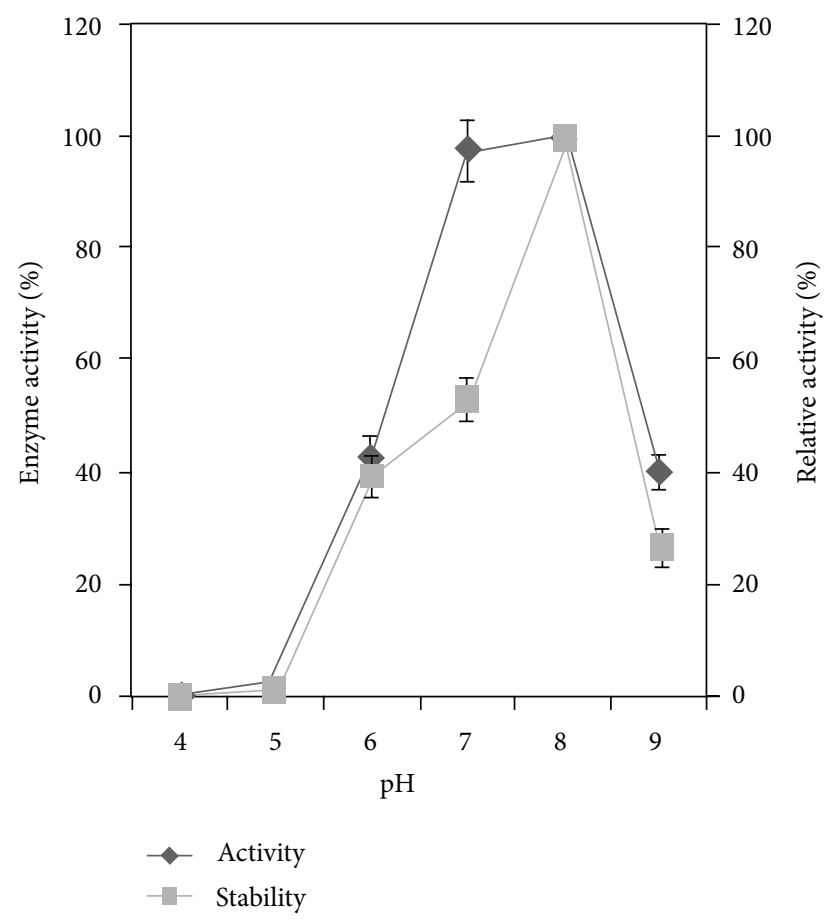

FIGURE 2: Effect of $\mathrm{pH}$ on phytase activity and stability. The Alcaligenes sp. was inoculated in the minimal medium containing $1 \%$ $(\mathrm{w} / \mathrm{v})$ sodium phytate as the sole phosphorus source and incubated at $37^{\circ} \mathrm{C}$ for $144 \mathrm{~h}$ in an orbital shaker at $150 \mathrm{rpm}$. The result was the mean of three different repeats. Error bar standard deviation.

stable at $\mathrm{pH} 8.0$ at which the relative enzyme activity was $100 \%$. The relative enzyme activity was $0.4 \pm 0.16,40 \pm 0.21$, $47 \pm 0.18$, and $27 \pm 0.24 \%$, at $\mathrm{pH} 4.0,5.0,6.0,7.0$, and 9.0, respectively, (Figure 2). This property was in accordance with the previously reported results. Some bacterial phytases have broad $\mathrm{pH}$ optima but are shifted towards a more basic $\mathrm{pH}$ range $[22,23]$. This enzyme was highly stable at $\mathrm{pH} 8.0(100 \%$ relative activity).

3.6. Effect of Temperature on Enzyme Activity and Stability. The effect of phytase activity was studied by incubating the reaction mixture at various temperatures $\left(30-70^{\circ} \mathrm{C}\right)$. The Alcaligenes phytase was highly active $\left(100 \%\right.$ activity) at $60^{\circ} \mathrm{C}$ (Figure 3). Optimal temperatures in which most phytases are active vary from 37 to $77^{\circ} \mathrm{C}$ [24]. Similar result was reported by Dvořáková [4] with Bacillus subtilis and with Pseudomonas syringae [25]. The relative enzyme activity was found to be high $(100 \%)$ at $60^{\circ}$. The relative enzyme activity was $59 \pm$ $1.6 \%, 68 \pm 2.7 \%, 92 \pm 3.4 \%$, and $86 \pm 5.3 \%$ at 30,40 , 50 , and $70^{\circ}$, respectively. Results indicated that the enzyme was stable up to 60 degrees of denaturing temperature. The relative enzyme activity was $64.7 \pm 4 \%$ at $70^{\circ} \mathrm{C}$ (Figure 3 ). This result shows that Alcaligenes phytase is relatively thermostable and is preferable for use in feed industry. This enzyme activity was comparable with Bacillus laevolacticus phytase [26].

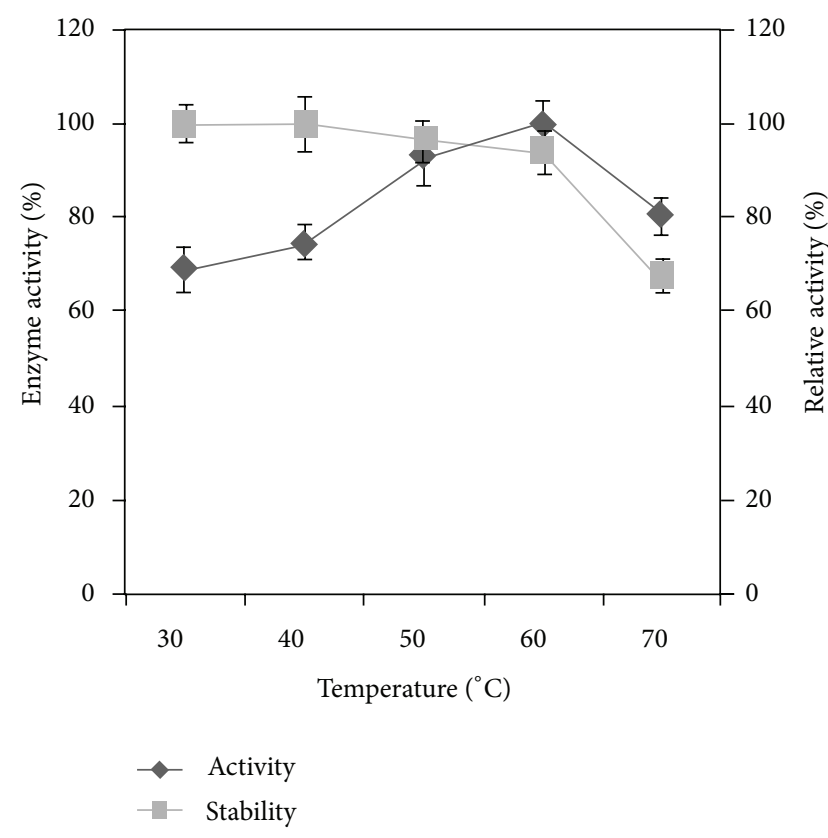

FIGURE 3: Effect of temperature on enzyme activity and stability. The enzyme sample was incubated with substrate for $30 \mathrm{~min}$ at temperatures ranging from 30 to $70^{\circ} \mathrm{C}$. The result was the mean of three different repeats. Error bar standard deviation.

3.7. Effect of Ions and Chemicals on Enzyme Activity. The effect of divalent ions on enzyme activity was investigated by allowing the divalent ions $(0.005 \mathrm{M})$ to react with the phytase sample. Divalent ions have been found to modulate Alcaligenes sp. phytase activity. However, it is difficult to determine whether the inhibitory effect of various metals is due to the direct binding of the metal ions to the enzyme, or whether the metal ions form poorly soluble complexes with phytic acid, thereby decreasing the active substrate concentration. Among divalent, $\mathrm{Ca}^{2+}$ enhanced the relative enzyme activity $(103 \pm 2.89 \%)$ when compared with the control (100\%). $\mathrm{Mn}^{2+}, \mathrm{Zn}^{2+}, \mathrm{Cu}^{2+}$, and $\mathrm{Mg}^{2+}$ inhibited the enzyme activity and the relative activity was $46 \pm 3.8 \%$, $39 \pm 2.92 \%, 73 \pm 1.3 \%$, and $21 \pm 0.8 \%$, respectively. EDTA also inhibited phytase activity $(49 \pm 1.3 \%)$. Similar results were obtained with Enterobacter sp. [23] and Yersinia kristeensenii [18].

3.8. Purification of Alcaligenes Phytase. Phytase was purified to homogeneity by sequential ammonium sulphate precipitation, anionic exchange chromatography, and gel filtration chromatography. The DEAE cellulose chromatography was still the major technique for purification of Alcaligenes phytase, because majority of contaminating proteins were removed at this step. In this step 3.57-fold purification was achieved with $25.3 \%$ yield. The recovery and purification were $7.07 \%$ - and 4.75 -fold, respectively, after sephadex G75 gel filtration chromatography. The purification procedure of phytase is summarized in Table 1. The molecular weight of the enzyme was found to be $41 \mathrm{kDa}$ (Figure 4). A twostep chromatographic process, similar to that employed with 
TABLE 1: Summary of the purification of the phytase from Alcaligenes sp.

\begin{tabular}{lccccc}
\hline Purification step & Total activity $(\mathrm{U})$ & Total protein $(\mathrm{mg})$ & Specific activity $(\mathrm{U} / \mathrm{mg})$ & Purification (fold) & Yield (\%) \\
\hline Crude enzyme & 980 & 182 & 5.38 & 1.0 & 100 \\
$80 \%\left(\mathrm{NH}_{4}\right)_{2} \mathrm{SO}_{4}$ & 562 & 84.6 & 6.64 & 57.3 \\
DEAE cellulose & 248 & 12.9 & 19.2 & 3.57 & 25.3 \\
Sephadex G-75 & 69.3 & 2.8 & 25.7 & 4.75 & 7.07 \\
\hline
\end{tabular}

TABLE 2: In vitro hydrolysis of plant phytate by alkaline-stable phytase from Alcaligenes sp.

\begin{tabular}{lc}
\hline Phytate source & $\begin{array}{c}\text { Released inorganic phosphorus } \\
(\mathrm{mg} / \mathrm{kg} \text { raw material })\end{array}$ \\
\hline Chick pea & $1930 \pm 23$ \\
Corn & $1740 \pm 86$ \\
Green pea & $1050 \pm 61$ \\
Ground nut & $845 \pm 35$ \\
Pearl pea & $1935 \pm 42$ \\
Chick feed & $1655 \pm 25$ \\
\hline
\end{tabular}

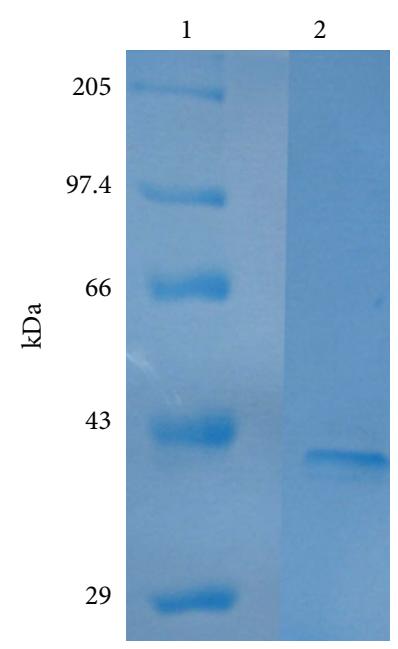

Figure 4: Sodium dodecyl sulphate polyacrylamide gel electrophoresis $(11 \%)$ of the purified phytase from Alcaligenes sp. Lane 1: molecular mass standards; Lane 2: purified sample from sephadex G-75.

Aspergillus ficuum [27], was followed. Homogeneity of the purified enzyme was revealed by SDS-PAGE which showed a single band with an apparent molecular mass of $41 \mathrm{kDa}$ (Figure 4). This result similar with a molecular mass was reported in bacteria [28].

3.9. Invitro Hydrolysis of Plant Phytate. In the present study various sources of plant phytates were used to investigate the effect of phytate, and the released inorganic phosphorus was measured. Plant phytates, namely, chick pea, corn, green pea, groundnut, pearl pea, and chick feed named "Layer Mash" were chosen as the substrate for in vitro hydrolysis. The maximal inorganic phosphorus release was obtained with pearl pea. The released inorganic phosphorus from these sources was significantly high (Table 2) than other reported results. A similar finding was reported by Fu et al. [18] with Yersinia kristeensenii. This property of the Alcaligenes phytase makes this a potential supplement in the animal feed industry. The plant phytate sources mentioned above are widely used as raw materials in the animal feed industry. Phytase cannot be fully used by agastric fish like carps, in which the $\mathrm{pH}$ of the digestive tract is about 6.5-8.4. Interestingly, Alcaligenes phytase was active and stable at this range of $\mathrm{pH}$. Thus, this phytase could be used effectively in the feed of monogastric animals and other organisms.

\section{Conclusions}

Phytate-rich plant feed restricts the bioavailability of phosphorus along with other minerals. It is clear that supplemental phytase can enhance the bioavailability of phosphorus and other minerals in plant-based feed. The Alcaligenes phytase had an optimum $\mathrm{pH}$ at alkaline range (7.0-8.0) and, fortunately, the fish gut $\mathrm{pH}$ fell at this range. Hence, this phytase could be used effectively to increase the bioavailability of phosphorus in feed. Further investigation about phytase application in fish feed is needed to study in in vivo. The progress in biotechnology of phytase is remarkable and attracting worldwide attention. Overproduction of phytase can be achieved by physical, chemical methods of mutagenesis and through recombinant DNA technology.

\section{References}

[1] A. Vohra and T. Satyanarayana, "Phytases: microbial sources, production, purification, and potential biotechnological applications," Critical Reviews in Biotechnology, vol. 23, no. 1, pp. 2960, 2003.

[2] U. Konietzny and R. Greiner, "Molecular and catalytic properties of phytate-degrading enzymes (phytases)," International Journal of Food Science and Technology, vol. 37, no. 7, pp. 791$812,2002$.

[3] B. F. Harland and E. R. Morris, "Phytate: a good or a bad food component?" Nutrition Research, vol. 15, no. 5, pp. 733-754, 1995.

[4] J. Dvořáková, "Phytase: sources, preparation and exploitation," Folia Microbiologica, vol. 43, no. 4, pp. 323-338, 1998.

[5] H. Fandrejewski, S. Raj, D. Weremko et al., "Apparent digestibility in experiment feeds and the effect of commercial phytase," Asian-Australasian Journal of Animal Sciences, vol. 10, no. 6, pp. 665-670, 1997.

[6] A. S. Sandberg and T. Andlid, "Phytogenic and microbial phytases in human nutrition," International Journal of Food Science and Technology, vol. 37, no. 7, pp. 823-833, 2002. 
[7] V. Ravindran, P. H. Selle, G. Ravindran, P. C. H. Morel, A. K. Kies, and W. L. Bryden, "Microbial phytase improves performance, apparent metabolizable energy, and ileal amino acid digestibility of broilers fed a lysine-deficient diet," Poultry Science, vol. 80, no. 3, pp. 338-344, 2001.

[8] M. Jorquera, O. Martínez, F. Maruyama, P. Marschner, and M. D. L. L. Mora, "Current and future biotechnological applications of bacterial phytases and phytase-producing bacteria," Microbes and Environments, vol. 23, no. 3, pp. 182-191, 2008.

[9] R. Greiner, U. Konietzny, and K. D. Jany, "Purification and characterization of two phytases from Escherichia coli," Archives of Biochemistry and Biophysics, vol. 303, no. 1, pp. 107-113, 1993.

[10] A. E. Richardson and P. A. Hadobas, "Soil isolates of Pseudomonas spp. that utilize inositol phosphates," Canadian Journal of Microbiology, vol. 43, no. 6, pp. 509-516, 1997.

[11] L. J. Yanke, H. D. Bae, L. B. Selinger, and K. J. Cheng, "Phytase activity of anaerobic ruminal bacteria," Microbiology, vol. 144, no. 6, pp. 1565-1573, 1998.

[12] A. Sajidan, A. Farouk, R. Greiner, P. Jungblut, E. C. Müller, and R. Borriss, "Molecular and physiological characterisation of a 3-phytase from soil bacterium Klebsiella sp. ASR1," Applied Microbiology and Biotechnology, vol. 65, no. 1, pp. 110-118, 2004.

[13] O. P. Walz and J. Pallauf, "Microbial phytase combined with amino acid supplementation reduces $\mathrm{P}$ and $\mathrm{N}$ excretion of growing and finishing pigs without loss of performance," International Journal of Food Science and Technology, vol. 37, no. 7, pp. 835-848, 2002.

[14] X. G. Lei and C. H. Stahl, "Biotechnological development of effective phytases for mineral nutrition and environmental protection," Applied Microbiology and Biotechnology, vol. 57, no. 4, pp. 474-481, 2001.

[15] S. J. Howson and R. P. Davis, "Production of phytatehydrolysing enzyme by some fungi," Enzyme and Microbial Technology, vol. 5, no. 5, pp. 377-382, 1983.

[16] H. H. Taussky and E. Skorr, "A microcolorimetric method for the determination of inorganic phosphorus," The Journal of Biological Chemistry, vol. 202, pp. 675-685, 1953.

[17] O. H. Lowry, N. J. Rosebrough, A. L. Farr, and R. J. Randall, "Protein measurement with the folin phenol reagent," The Journal of Biological Chemistry, vol. 193, no. 1, pp. 265-275, 1951.

[18] D. Fu, H. Huang, H. Luo et al., "A highly pH-stable phytase from Yersinia kristeensenii: cloning, expression, and characterization," Enzyme and Microbial Technology, vol. 42, no. 6, pp. 499-505, 2008.

[19] U. K. Laemmli, "Cleavage of structural proteins during the assembly of the head of bacteriophage T4," Nature, vol. 227, no. 5259, pp. 680-685, 1970.

[20] G. Q. Lan, N. Abdullah, S. Jalaludin, and Y. W. Ho, "Optimization of carbon and nitrogen sources for phytase production by Mitsuokella jalaludinii, a new rumen bacterial species," Letters in Applied Microbiology, vol. 35, no. 2, pp. 157-161, 2002.

[21] Y. M. Choi, H. J. Suh, and J. M. Kim, "Purification and properties of extracellular phytase from bacillus sp. KHU-10," Protein Journal, vol. 20, no. 4, pp. 287-292, 2001.

[22] M. Shimizu, "Purification and characterization of phytase from Bacillus subtilis (natto) N-77," Bioscience, Biotechnology, and Biochemistry, vol. 56, pp. 1266-1269, 1992.

[23] S. J. Yoon, Y. J. Choi, H. K. Min et al., "Isolation and identification of phytase-producing bacterium, Enterobacter sp. 4, and enzymatic properties of phytase enzyme," Enzyme and Microbial Technology, vol. 18, no. 6, pp. 449-454, 1996.
[24] A. Hara, S. Ebina, A. Kondo, and T. Funaguma, "A new type of phytase from pollen of Typha latifolia L.", Agricultural and Biological Chemistry, vol. 49, pp. 3539-3544, 1985.

[25] J. S. Cho, C. W. Lee, S. H. Kang et al., "Purification and characterization of a phytase from Pseudomonas syringae MOK1," Current Microbiology, vol. 47, no. 4, pp. 290-294, 2003.

[26] H. K. Gulati, B. S. Chadha, and H. S. Saini, "Production of feed enzymes (phytase and plant cell wall hydrolyzing enzymes) by Mucor indicus MTCC 6333: purification and characterization of phytase," Folia Microbiologica, vol. 52, no. 5, pp. 491-497, 2007.

[27] A. H. Ullah and D. M. Gibson, "Extracellular phytase (E.C. 3.1.3.8) from Aspergillus ficuum NRRL 3135: purification and characterization," Preparative Biochemistry, vol. 17, no. 1, pp. 6391, 1987.

[28] R. Greiner and A. E. Farouk, "Purification and characterization of a bacterial phytase whose properties make it exceptionally useful as a feed supplement," Protein Journal, vol. 26, no. 7, pp. 467-474, 2007. 

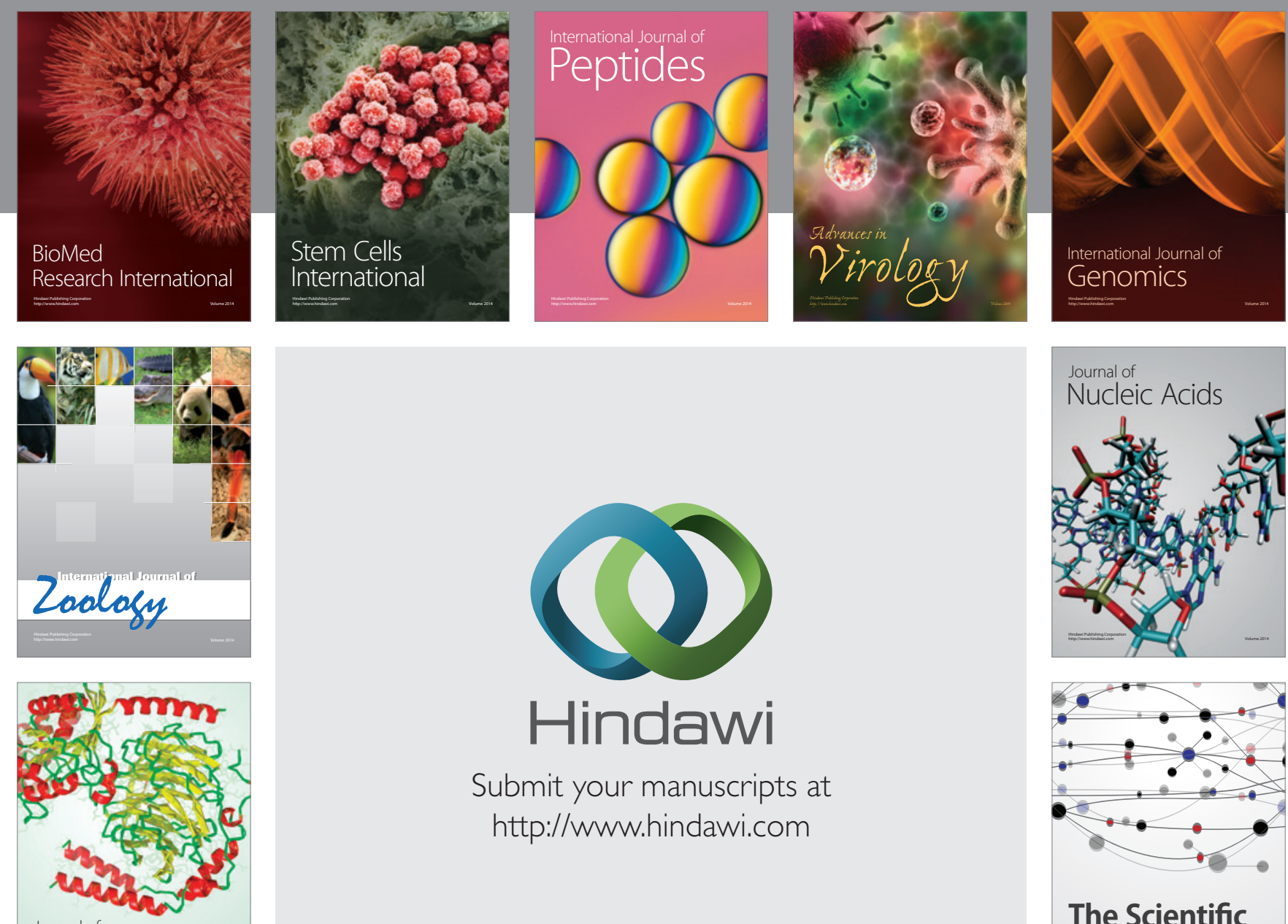

Submit your manuscripts at

http://www.hindawi.com

Journal of
Signal Transduction
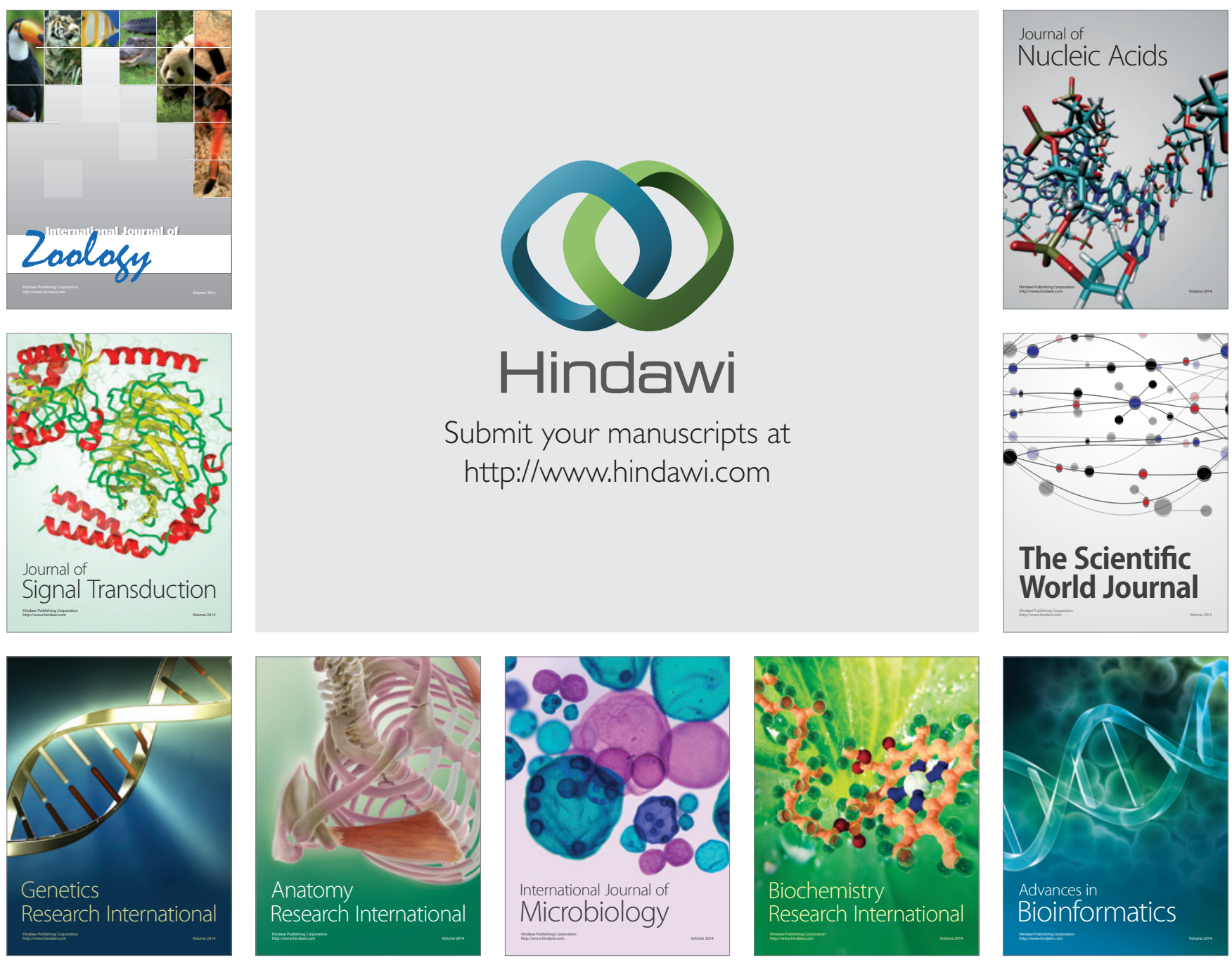

The Scientific World Journal
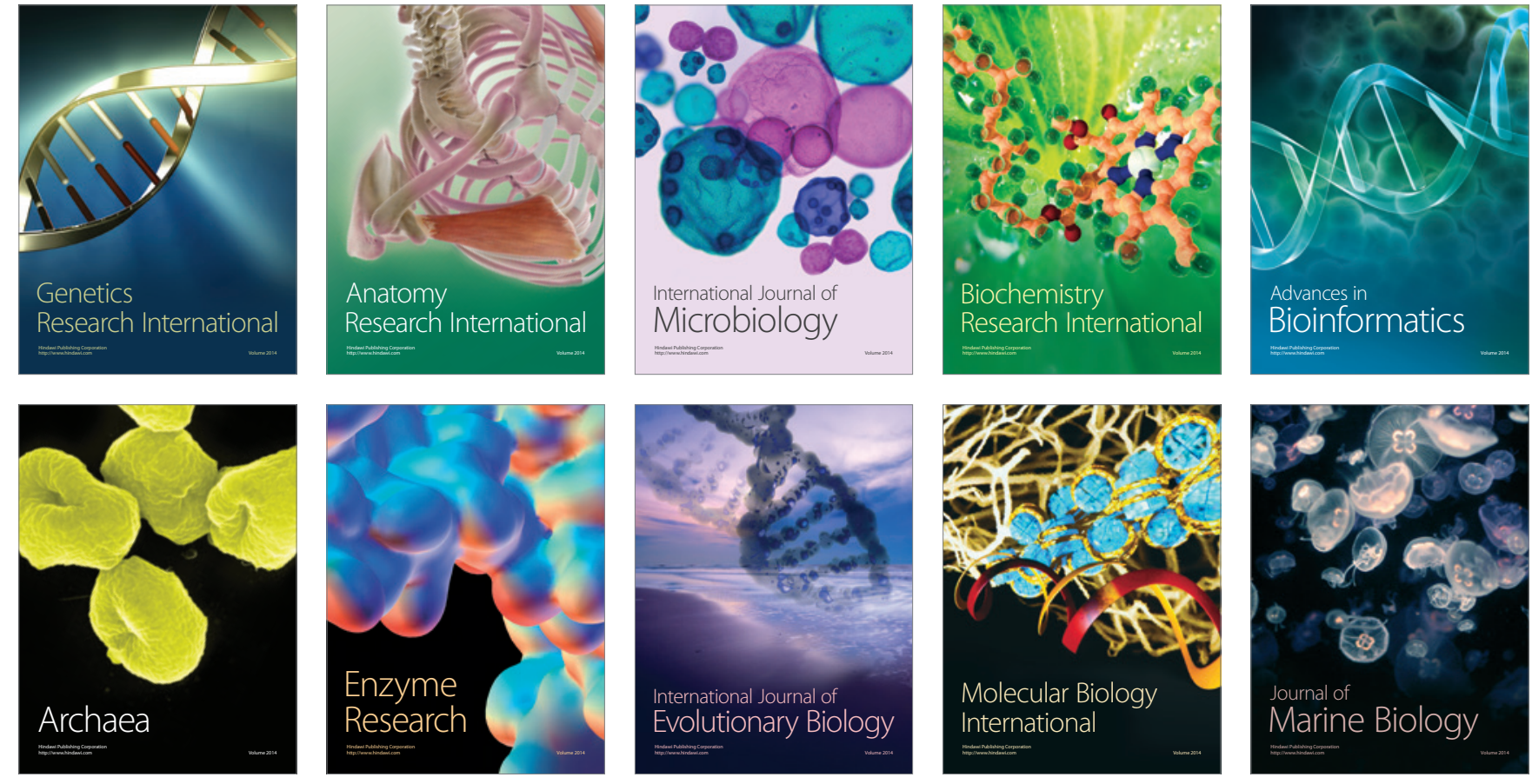